\title{
Developing integrated approaches to nitrogen management
}

Book or Report Section

Published Version

Oenema, O., Salomez, J., Branquinho, C., Budnakova, M., Cermak, P., Geupel, P., Johnes, P., Tomkins, C., Spranger, T., Erisman, J. W., Palliere, C., Maene, L., Alonso, R., Maas, R., Magid, J., Sutton, M. A. and van Grinsven, H. (2011) Developing integrated approaches to nitrogen management. In: Sutton, M. A., Howard, C. M., Erisman, J. W., Billen, G., Bleeker, A., Grennfelt, P., van Grinsven, H. and Grizzetti, B. (eds.) European Nitrogen Assessment. Cambridge University Press, UK, pp. 541-550. ISBN 9781107006126 Available at https://centaur.reading.ac.uk/20872/

It is advisable to refer to the publisher's version if you intend to cite from the work. See Guidance on citing.

Publisher: Cambridge University Press

All outputs in CentAUR are protected by Intellectual Property Rights law, including copyright law. Copyright and IPR is retained by the creators or other copyright holders. Terms and conditions for use of this material are defined in the End User Agreement. 


\section{www.reading.ac.uk/centaur}

\section{CentAUR}

Central Archive at the University of Reading

Reading's research outputs online 


\title{
Developing integrated approaches to nitrogen
} management

\author{
Lead author: Oene Oenema
}

Contributors: Joost Salomez, Cristina Branquinho, Michaela Budňáková, Pavel Čermák, Markus Geupel, Penny Johnes, Chris Tompkins, Till Spranger, Jan Willem Erisman, Christian Pallière, Luc Maene, Rocio Alonso, Rob Maas, Jacob Magid, Mark A. Sutton and Hans van Grinsven

\section{Executive summary}

\section{Nature of the problem}

- Reactive nitrogen $\left(\mathrm{N}_{\mathrm{r}}\right)$ occurs in different forms, arises from a wide range of activities and sources, and leads to environmental impacts over different spatial and temporal scales.

- Integrated approaches to $\mathrm{N}$ management are anticipated to provide more effective (larger decreases in unwanted emissions) and /or more efficient (less side effects, less costs) policy measures than policy measures based on single sources and pollutant species.

- There are many notions of integrated approaches, but as yet little consensus about the best integrated approaches. There is also little quantitative empirical evidence of the performance of these approaches in practice.

- The pitfall of integrated approaches is that they may be more complex to agree, leading to a delayed implementation.

\section{Approaches}

- Based on recent literature and a discussion among experts, the present chapter provides a conceptual framework for developing integrated approaches to $\mathrm{N}$ management.

- Whilst discussing the framework, various examples of existing partially integrated $\mathrm{N}$ management approaches have been considered.

- A package of key actions in different sectors is envisaged that, together, should contribute to further developing integrated approaches to $\mathrm{N}$ management in the future

\section{Key findings/state of knowledge}

- The conceptual framework developed here distinguishes five dimensions of integration: (i) vertical dimension, i.e., cause-effect relationships of $\mathrm{N}$ species; (ii) horizontal dimension, i.e., integration of all $\mathrm{N}$ species via for example $\mathrm{N}$ budgets; (iii) integrating $\mathrm{N}$ management with the management of other elements, such as $\mathrm{SO}_{2}, \mathrm{P}, \mathrm{CO}_{2}$, and $\mathrm{CH}_{4}$, (iv) integrating stakeholders views, and (v) regional integration, i.e., integration over spatial scales.

- The toolbox for developing integrated approaches to $\mathrm{N}$ management has various types of tools, including systems analyses, communication, integrated assessment modeling, $\mathrm{N}$ budgeting, stakeholder dialogue and chain management.

- Integrated approaches may be most applicable to agriculture, because of the role of $\mathrm{N}$ in food, feed and fiber production and the relative large diffuse $\mathrm{N}$ losses from multiple sources in multiple forms.

\section{Major uncertainties/challenges}

- There is as yet little empirical evidence of the perceived increased effectiveness and efficiency of integrated $\mathrm{N}$ management approaches relative to single $\mathrm{N}_{\mathrm{r}}$ species and single $\mathrm{N}_{\mathrm{r}}$ source management approaches. Potentially, integrated $\mathrm{N}$ management approaches may also achieve a broader set of societal targets simultaneously, but there is as yet little empirical evidence for this promise.

- The 'optimum' level of integration likely depends on many factors, and it remains a challenge to define such optima for various situations and cases.

The European Nitrogen Assessment, ed. Mark A. Sutton, Clare M. Howard, Jan Willem Erisman, Gilles Billen, Albert Bleeker, Peringe Grennfelt, Hans van Grinsven and Bruna Grizzetti. Published by Cambridge University Press. (๑) Cambridge University Press 2011, with sections @ authors/European Union. 


\section{Recommendations}

- A package of seven key actions is identified that would contribute to developing an integrated approach to better management of nitrogen in the environment.

- Improving nitrogen use efficiency in crop production.

- Improving nitrogen use efficiency in animal production.

- Increasing the fertilizer $\mathrm{N}$ equivalence value of animal manure.

- Low-emission combustion and energy-efficient systems.

Recycling nitrogen (and phosphorus) from waste water systems.

Societal consumption patterns: energy and transport saving.

Societal consumption patterns: lowering animal protein consumption.

\subsection{Introduction}

This chapter discusses integrated approaches to nitrogen (N) management and explores options for further development of these approaches. The notion that $\mathrm{N}$ needs to be managed in a comprehensive and integrated way follows from the understanding that reactive nitrogen $\left(\mathrm{N}_{\mathrm{r}}\right)$ once formed is involved in a sequence of transfers, transformations and environmental effects (Galloway and Cowling, 2002; Galloway et al., 2008), that the economic costs of emissions abatement are often high, and that the management of a single source and/or a single $\mathrm{N}_{\mathrm{r}}$ species, especially agriculture, is not always efficient. There are three main sources of $\mathrm{N}_{\mathrm{r}}$ emissions (agriculture, combustion and wastes), with numerous sub-sources, and five main threats of these emissions (water quality, air quality, climate change, biodiversity loss, and soil quality, with various sub threats (Sutton et al., 2011, Chapter 5, this volume). Managing each single sub-source of $\mathrm{N}_{\mathrm{r}}$ emissions (mainly $\mathrm{NH}_{3}, \mathrm{~N}_{2} \mathrm{O}, \mathrm{NO}_{\mathrm{x}}$, $\mathrm{NO}_{3}^{-}$) with their impacts in isolation is virtually impossible, because of the bewildering number of sources and the complexity of the cause-effect relationships. The so-called 'nitrogen cascade' clearly illustrates the complexity of the global $\mathrm{N}$ cycle and also the need for an integrated approach to $\mathrm{N}$ management (Galloway et al., 2003).

Fundamental arguments for using integrated approaches to $\mathrm{N}$ management follow also from the first and second law of thermodynamics. Basically, the first law implies that the element $\mathrm{N}$ can be transformed into different species, but it can not be 'destroyed. The second law of thermodynamics basically implies that $\mathrm{N}$ has the natural tendency 'to dissipate' into the environment. Nitrogen has even been termed 'double mobile', together with carbon and sulfur (Smil, 2001), because these elements are mobile in both air and water (and soil).

Though there is scientifically sound underpinning for considering the management of the various $\mathrm{N}$ sources in a more holistic and integrated manner, there are also barriers and constraints for more integrated approaches, such as the compartmental and discipline oriented structure and organization of policy departments and science groups. There is also discussion about 'what and how to integrate?'. In EU policy, there is an increasing tendency for developing more integrated (economicenvironmental) approaches, but many current environmental policies still have a narrow scope as regards $\mathrm{N}$ management (Oenema et al., 2011; Bull et al., 2011, Chapters 4 and 25, this volume). The discussion is in part also confused by lack of clear and accepted definitions about the terms 'integrate' and 'management' (see Supplementary materials). This discussion is not limited to $\mathrm{N}$; there are also pleas for integrating natural sciences and economy in decision making so as to enhance environmental protection and resource use efficiency (Hall et al., 2001).

The objectives of this chapter are (i) to discuss current approaches to integrated $\mathrm{N}$ management and to present a conceptual framework for these approaches, and (ii) to propose some further integrated approaches to $\mathrm{N}$ management, including a package of key actions that would contribute to improved overall $\mathrm{N}$ management in Europe. Integration of approaches to coordinate efforts at the levels of policy and supranational organizations are discussed in Chapter 25 (Bull et al., 2011).

\subsection{Conceptual framework for integrated approaches}

\subsubsection{Integration dimensions}

Integration is perceived as combining separate elements and aspects in an organized way, so that the constituent units function cooperatively (see Supplementary materials). There are various integrated approaches to $\mathrm{N}$ management in practice, with various degrees of combining separate elements and aspects. We postulate that five different dimensions (categories of elements and aspects) of integration in $\mathrm{N}$ management can be distinguished conveniently, namely: (i) vertical integration, (ii) horizontal integration, (iii) integration of other elements, (iv) integration of stakeholders' views, and (v) regional integration (Figure 23.1). These dimensions are further discussed below, while referring to existing policies.

\subsubsection{Vertical and horizontal integration}

In economy, ecology and also societies, it is helpful to think in terms of levels of organizational hierarchies. A hierarchy is defined as an arrangement into a graded series of entities. A hierarchy can link entities either vertically or horizontally.

Vertical integration in economy is the linkage of upstream suppliers to downstream buyers (Figure 23.2). Vertical integration results in more control, higher production efficiency and more marketing power. Vertical integration in ecology is the functional linkage of autotrophic producers to heterotrophic consumers (including herbivores, carnivores, omnivores and saprovores), expressed in the idea of a food chain. In terms of $\mathrm{N}$ management, vertical integration relates to linking 'cause and 


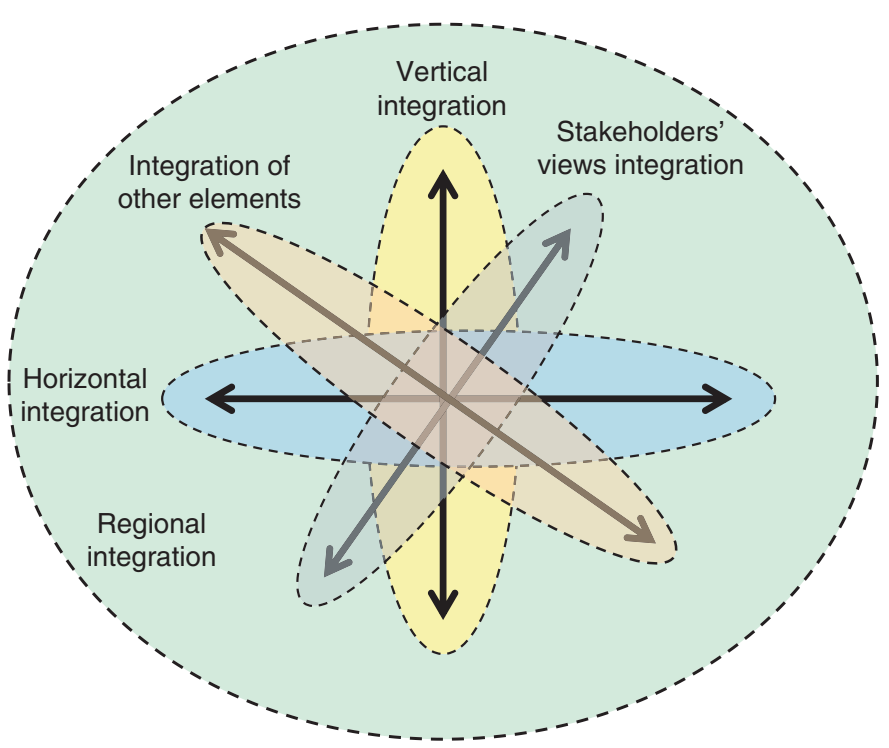

Figure 23.1 Framework of integrated $\mathrm{N}$ management, with five dimensions (see text). (Source: original material for this chapter.)

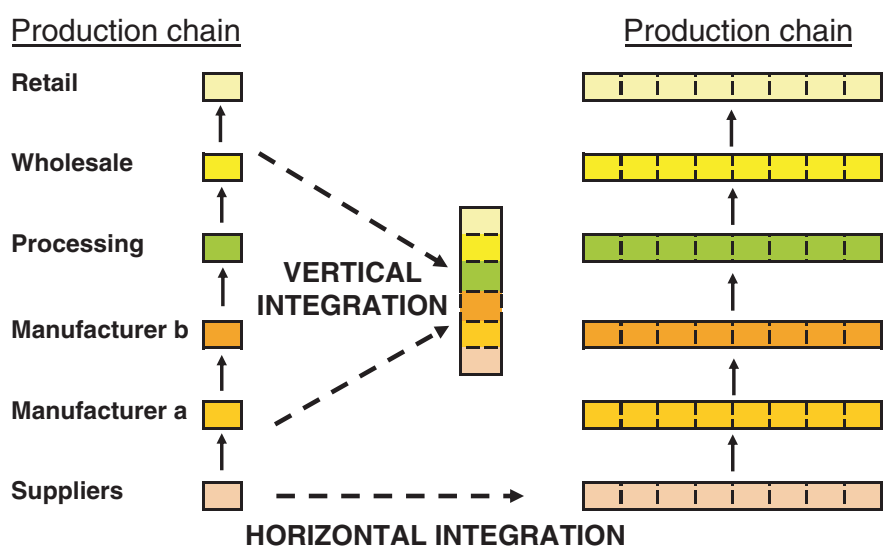

Figure 23.2 Conceptual visualization of vertical and horizontal integration of firms in production chains. (Source: original material for this chapter.)

effect', and 'source and impact'. Examples of vertical integration are the 'driving forces, pressures, state, impact and response' framework (DPSIR-framework; see OECD, 1991; EEA, 1995) and the 'effects- based approach' to emissions abatement policies as applied in the Gothenburg Protocol (UNECE, 1999). Essentially, vertical integration is the basis of all current $\mathrm{N}$ policies in Europe, as the human health effects and ecological impacts are the legitimate of these policies, while the selection of abatement measures is based in part on the economic consequences (cost-effectiveness). Thus, the gains in human health and biodiversity are weighted against the cost of the emission abatement. A full cost-benefit analysis is still complicated, because of the difficulty of attaching monetary values to human health and ecosystems, although significant progress has been described in Chapter 22 (Brink et al., 2011, Chapter 22 this volume). Evidently, including cost-benefit analyses would make vertical integration of $\mathrm{N}$ management more complete.

Horizontal organization is related to up-scaling so as to benefit from larger scale and number. Horizontal integration is the linkage of elements of similar entity, for example when similar firms merge to benefit from the economics of scale (Figure 23.2). Also the herding of animals, schooling of fishes, flocking of birds and colonies of ants and termites can be considered as forms of horizontal integration. Horizontal integration in $\mathrm{N}$ management relates to combining $\mathrm{N}$ species, $\mathrm{N}$ sources and $\mathrm{N}$ emissions within a certain area in the management plan. Partial forms of horizontal integration are in the Gothenburg Protocol (e.g., all anthropogenic $\mathrm{NO}_{\mathrm{x}}$ sources and all $\mathrm{NH}_{3}$ sources have been included, but $\mathrm{N}_{2} \mathrm{O}$ emissions to air and $\mathrm{N}$ leaching to waters are not included) and the EU Nitrates Directive (all $\mathrm{N}$ sources in agriculture have to be considered for reducing $\mathrm{NO}_{3}$ leaching to waters, but $\mathrm{NH}_{3}$ and $\mathrm{N}_{2} \mathrm{O}$ emissions to air are not addressed explicitly). Similarly, the emission of gaseous $\mathrm{N}_{2}$ through denitrification is not considered in these policies. Although emission of gaseous $\mathrm{N}_{2}$ does not lead directly to adverse environmental effects, its release can be considered as a waste of the energy used to produce $\mathrm{N}_{\mathrm{r}}$, indicating the need that $\mathrm{N}_{2}$ emissions should also be addressed.

Conceptually, the N cascade model (Galloway et al., 2003; Sutton et al., 2011, Chapter 5, this volume) is a nice example of horizontal integration, but this model has not been made operational for management actions yet. The $\mathrm{N}$ cascade is also a conceptual model for vertical integration, especially when cost-benefit analyses are included.

\subsubsection{Integration of other elements and compounds}

Emissions of nitrogen oxides $\left(\mathrm{NO}_{\mathrm{x}}\right)$, ammonia $\left(\mathrm{NH}_{3}\right)$ and sulphur dioxide $\left(\mathrm{SO}_{2}\right)$ to air have rather similar environmental effects (air pollution, acidification, eutrophication), and that is the reason that the effects-based approach of the CLRTAP Gothenburg Protocol and the EU National Emission Ceiling Directive address each of $\mathrm{NO}_{\mathrm{x}}, \mathrm{NH}_{3}$ and $\mathrm{SO}_{2}$. Similarly, emissions of $\mathrm{N}_{\mathrm{r}}$ and phosphorus $(\mathrm{P})$ to surface waters both contribute to eutrophication and biodiversity loss, and thus EU policies related to combat eutrophication of surface waters address $\mathrm{N}$ and P simultaneously (Oenema et al., 2011, Chapter 4, this volume). Further, the $\mathrm{N}$ and carbon (C) cycles in the biosphere are intimately linked, and the perturbations of these cycles contribute to increased emissions of $\mathrm{CO}_{2}, \mathrm{CH}_{4}$ and $\mathrm{N}_{2} \mathrm{O}$ to the atmosphere. Climate change policies address these greenhouse gases simultaneously. Nitrogen may also affect $\mathrm{CO}_{2}$ emissions through its effect on carbon sequestration in the biosphere and by alteration of atmospheric chemistry (Butterbach-Bahl et al., 2011, Chapter 19, this volume).

Evidently, there are two main reasons to integrate $\mathrm{N}$ management with the management of specific other elements (compounds) in environmental policy, namely (i) the other elements (compounds) have similar environmental effects, and (ii) interactions between $\mathrm{N}$ species and these other elements and compounds. From the practitioner point of view, there can be benefits when managing $\mathrm{N}$ and specific other elements simultaneously. This holds for example for $\mathrm{NO}_{\mathrm{x}}$ and $\mathrm{SO}_{2}$ (and soot) from combustion sources, and $\mathrm{N}$ and $\mathrm{P}$ in agriculture and sewage waste treatment. 


\subsubsection{Stakeholder involvement and integration}

Any $\mathrm{N}$ management policy, whether integrated or not, needs to be:

(i) policy-relevant; i.e., address the key environmental and other issues;

(ii) scientifically and analytically sound;

(iii) cost effective; i.e., costs have to be in proportion to the value of environmental improvement, and

(iv) politically legitimate; i.e., acceptable and fair to users.

When one or more of these constraints are not fulfilled, the management policy will be less effective, either through a delay in implementation and/or through poor implementation and performance. Satisfying the aforementioned constraints requires communication between actors from policy, science and practice. Tuinstra et al. (2006) argue that the credibility, legitimacy and relevance of the science-policy interaction are to a large extent determined by 'boundary' work in an early stage of the communication process between policy and science. They analyzed the communication process between policy and science in the Convention for Long-range Transboundary Air Pollution (CLRTAP) and the EU National Emission Ceiling Directive. Boundary work is defined here as the practice of maintaining and withdrawing boundaries between science and policy, thereby shaping and reshaping the science-policy interface.

Of similar importance is the communication with practitioners, i.e., the actors that ultimately have to execute management actions in practice. Integrating their views has to be done also as early as possible during the design phase of the $\mathrm{N}$ management plans and measures, because the practitioners, in the end, have to implement the management measures. Integrating views of practitioners may range from public consultation procedures, hearings to participatory approaches and learning; the latter take the practitioners' perspectives fully into account and give them a say also in planning and managing. A good example of the latter approach is the EU Water Framework Directive (EC, 2010), which requires full stakeholder involvement for the establishment of water basin management plans.

Integration of practitioners' views does not necessarily lead to faster decision making; on the contrary, the decision making process often takes more time. Public consultation procedures can be very long-winded, though techniques like multi-criteria decision making (MCDM) may support decision making effectively; this approach aims at deriving a way out of conflicts and to come to a compromise in a transparent process. Integration of practitioners' views may ultimately improve the acceptance of the management strategies, and thereby facilitate the implementation of the management strategies in practice.

\subsubsection{Regional integration}

Regional integration or 'integration of spatial scales' is considered here as the fifth dimension of integration. Regional integration aims at enhanced cooperation between regions. It relates to integration of markets and to harmonization of governmental polices and institutions between regions through political agreements, covenants and treaties (Bull et al., 2011). Arguments for regional integration are: (i) enhancing markets, (ii) creation of a level-playing field, (iii) the transboundary nature of environmental pollutions and (iv) the increased effectiveness and efficiency of regional policies and related management measures.

In terms of $\mathrm{N}$ management, regional integration relates, for example, to the harmonization and standardization of environmental policies across European Union and for air pollution in the UNECE region (Oenema et al., 2011; Bull et al., 2011). The water basin or catchment management plans developed within the framework of the EU Water Framework Directive are also a form of regional integration. Here, water quantity and quality aspects are considered in an integrated way for a well-defined catchment.

The trend toward regional integration during the last decades does not necessarily mean that local management actions are less effective and/or efficient. Local actions can be made site-specific and, as a consequence, are often more effective than generic measures. This holds both for households, farms and firms, and especially when actors can have influence on the choice of actions. Also, the motivation for contributing to the local environment and nature can be larger than for contributing to the improvement of the environment in general (see Kahn, 2001).

\subsection{Tools for integrated approaches to N management}

The toolbox for developing integrated approaches to $\mathrm{N}$ management contains tools that are uniformly applicable, as well as highly specific, suitable for just one dimension of integration. Important common tools are: (i) systems analysis, (ii) communication, (iii) $\mathrm{N}$ budgeting, (iv) integrated assessment modeling and cost-benefit analyses, (v) logistics and chain management, and (vi) stakeholder dialogue.

The starting point for developing integrated approaches is 'systems analysis', as it provides information that is needed for all dimensions of integration. Systems analysis allows for identifying and quantifying components, processes, flows, actors, interactions and inter-linkages within and between systems, and provides a practical tool for discussing integrated approaches to $\mathrm{N}$ management. In essence, it encompasses the view that changes in one component will promote changes in all of the components of the systems (Odum, 1996). These type of tools are being used especially by the science-policy interface.

A second tool for developing integrated approaches is communication. Communication is transferring information, but at the same time the tool for raising awareness and for explaining the meaning, purpose, targets and actions of integrated approaches to $\mathrm{N}$ management to all actors involved. Clear communication is important, as there is often ambiguity in the use of the terms 'integrated' and 'management' and insufficient clarity about the objectives and required actions. Communication can help make the concept transparent and thereby can facilitate the adoption of targets and measures in practice. 
A third type of tool is nitrogen balances, which quantifies the differences between nitrogen inputs and outputs of systems and of compartment of these systems. This is an indispensable tool for horizontal integration and in part also vertical integration; it integrates over $\mathrm{N}$ sources and $\mathrm{N}$ species for well-defined areas and/or components. Input-output $\mathrm{N}$ balances have been proven to be easy-to-understand management tools for farmers (Jarvis et al., 2011, Chapter 10 this volume), plant managers and policy managers (see Supplementary materials). Input-output balances and budgets are flexible tools, but require uniform definitions and conventions to circumvent bias (Oenema et al., 2003; de Vries et al., 2011, Leip et al., 2011, Chapters 15 and 16, this volume). Life Cycle Assessment (LCA) is an approach to account for emissions and resources during the entire life cycle of a product. It can be seen also as a tool for horizontal integration, similar to input-output budgets, but it integrates also over time. This type of tool is especially used by scientists, while also being relevant for use by practitioners.

A fourth type of tool is integrated assessment modeling, including ecological food print analyses, cost-benefit analyses and target setting. These tools are indispensable for vertical integration, relating cause and effect to impact, and analyzing the responses by society (actors). The 'DPSIR model' is a conceptual tool for analyzing cause-effect relationships. It relates Driving forces of environmental change (population growth, economic growth, etc.), to Pressures on the environment (e.g., $\mathrm{N}_{\mathrm{r}}$ emissions), to State of the environment (e.g., water quality), to Impacts on population, economy and ecosystems, and finally to the Response of the society (OECD, 1991; EEA, 1995). Integrated assessment modeling is the interdisciplinary process that quantifies and analyzes these cause-effect relationships in the current situation (using empirical data and information) and for future conditions (using scenario analyses), in order to facilitate the framing of strategies. Examples include reviews of the Gothenburg Protocol by the Taskforce on Integrated Assessment Modelling of the UNECE Convention on Longrange Transboundary Air Pollution (TFIAM/CIAM, 2007). Cost-Benefit Analysis (CBA) go a step further by expressing costs and benefits of policy measures in monetary terms. However, attaching financial values to for example improvement of human health and increased ecosystem protection is not without its challenges (Brink et al., 2011). This type of tool is generally applied at the science-policy interface. They are also used to assess uncertainties in the cause-effect relationships and in the effects of management measures.

A fifth tool for integrated approaches to $\mathrm{N}$ management is 'logistics and chain management'. This is the planning and management of activities, information and $\mathrm{N}$ sources in firms, installations and departments between the point of origin and the point of consumption. In essence, logistics and chain management integrate the supply and demand within and across companies. Logistics and chain management is especially important for $\mathrm{N}$ fertilizer producing companies, animal feed companies, transport and distribution sectors, processing industries, companies involved in recycling (sewage waste, composts, etc.), but also large farms. This type of tool is used especially by practitioners.
A sixth type of tool is stakeholder dialogue, including Multi Criteria Decision Analysis (MCDA), learning and participatory approaches. Evidently, this type of tool is indispensable for addressing the views of actors in $\mathrm{N}$ management issues (the 4th dimension of integration). The intention of stakeholder dialogue is to get people from different perspectives to enter a result-oriented conversation. Stakeholder dialogue is interaction between different stakeholders to address specific problems related to competing interests and competing views on how $\mathrm{N}$ and other resources should be used and managed. Rotmans (2003) describes the roles of stakeholders, networking, and self-governance in transition management. MCDA has been used in the water quality context and also in setting strategies for $\mathrm{NH}_{3}$ control in a wider context (including dietary change). It is a good way of involving different stakeholder interests and for dealing with uncertainties.

Further, high-level meetings and resulting treaties are seen as a tool to achieve regional integration of $\mathrm{N}$ management measures. Regional integration is the most complex and encompassing way of integration. Also, there are many ways for and stages of regional integration, with not just one most superior outcome (in terms of ratification, exemptions, delayed implementation, etc.). This offers the opportunity of creating flexibility (Bull et al., 2011).

Finally, integrated approaches to $\mathrm{N}$ management can be expected to have different policy targets than policies oriented toward single $\mathrm{N}$ sources and $\mathrm{N}$ species. Based in part on the critical-load concept and emission ceilings for $\mathrm{N}$ species developed under the CLRTAP Gothenburg Protocol, it is suggested that incentive-based $\mathrm{N}$ budgets and $\mathrm{N}_{\mathrm{r}}$ ceilings per area, sector and or activity could be useful indicators, because they integrate multiple elements of $\mathrm{N}$ effects in the environment (see also Supplementary materials). The usefulness and analytical soundness of such indicators have to be further explored.

\subsection{Developing integrated N management approaches further}

Integrated $\mathrm{N}$ management approaches have the potential of achieving various societal objectives and targets simultaneously more effectively and efficiently than disciplinary, single-issue approaches. The combination of achieving broader societal targets at a higher cost-effectiveness (without pollution swapping and/or other negative side-effects) is indeed a main driving force for developing integrated approaches. Such potential benefits may be achieved on the long term only, as there are possible disadvantages in the short term (see Supplementary materials). Like any other management approaches, integrated management approaches have to be also policy-relevant, scientific-analytical sound, and political legitimate; i.e., acceptable and fair to users.

The perceived greater effectiveness and efficiency of integrated approaches may also follow from a greater acceptability by and fairness to users. An integrated approach to $\mathrm{N}$ also holds the promise of decreasing the risks on inconsistency and pollution swapping. However, integrated approaches have higher demands as regards interdisciplinary cooperation and 
consensus building both in the domains of science, policy and practice (Tuinstra et al., 2006). As a consequence, integrated $\mathrm{N}$ management approaches may be more expensive, have lower initial adoption and have lower effectiveness, initially. By contrast, integrated approaches can be expected to lead to more efficient and cost-effective nitrogen management in the long term.

There are various integrated $\mathrm{N}$ management policy measures existing in EU in practice already, though most of these may be considered as partial integration. The reform of the Common Agricultural Policy with cross compliance regulation, the National Emission Ceiling Directive (NECD) and the Water Framework Directive are examples of partial integrated approaches in current EU policy. It is therefore a remaining challenge to link and integrate the policies related to $\mathrm{N}$ in air (for example NECD) and those related to $\mathrm{N}$ in waters (for example Water Framework Directive and its related Directives) more intimately. The quantitative extent to which such increased linkage would yield a more optimal level of integration and increased cost-effectiveness needs to be further explored.

Evidently, the challenge is to combine and coordinate those separate elements that provide the optimum level of integration, so as to ensure an organized and structured whole. Against this background, we first derive criteria (see below) and then consider actions for further integration of $\mathrm{N}$ management approaches (Section 23.5), while acknowledging that some integrated $\mathrm{N}$ management approaches are existing already (see Supplementary materials).

The following criteria can be considered for identifying the most suitable 'key actions' (or intervention points) of an integrated approach to $\mathrm{N}$ management.

- Any approach should consider that nitrogen is needed for food, feed and fiber production and that the production of food, feed and fiber is accompanied with diffuse losses of $\mathrm{N}$ to the environment. The beneficial effects of $\mathrm{N}_{\mathrm{r}}$ use have to be weighted against the adverse effects to the wider environment.

- Integrated approaches should lead to increased costeffectiveness of the policy measures from a societal point of view, and to less pollution swapping when compared to more disciplinary, single-issue approaches.

- Strategies that decrease more than one form of $\mathrm{N}_{\mathrm{r}}$ pollution are considered especially beneficial, such as those improving $\mathrm{N}$ use efficiency in food, feed and fiber production.

- 'The polluter should pay' is a common principle in environmental protection and should hold also for integrated approaches to $\mathrm{N}$ management. Yet, the addressees of integrated approaches to $\mathrm{N}$ management may be different from those of more disciplinary, singleissue approaches. Addressing consumers' behavior can be equally important as addressing producers' behavior (see also Supplementary materials).

- The optimal mix of instruments will depend on the objectives of the integrated management approach, the region-specific conditions and the rationale of the addressees; Incentive based strategies appear more attractive to practitioners than regulatory instruments, as they provide greater flexibility to the practitioners (OECD, 2007).

- The full suite of key actions must consider all major sources of reactive nitrogen and lead to appropriate sharing of efforts and benefits between the actors.

- Any strategy should be subject to comprehensive stakeholder discussion to ensure buy in.

\subsection{Key actions for integrated nitrogen management}

\subsubsection{Key actions for the global level}

Galloway et al. (2008) discussed four key actions for reducing $\mathrm{N}_{\mathrm{r}}$ release to the environment at global level. They suggested that the following package of four measures could reduce total global $\mathrm{N}_{\mathrm{r}}$ emissions by $\sim 50 \mathrm{Tg}$ per year, which is about onethird of the total estimated anthropogenic $\mathrm{N}_{\mathrm{r}}$ release into the wider environment as of 2005.

(1) Using best available techniques, $\mathrm{N}_{\mathrm{r}}$ release from combustion may be decreased by $\sim 18 \mathrm{Tg}$ per year.

(2) Increasing fertilizer $\mathrm{N}$ use efficiency may reduce fertilizer $\mathrm{N}$ use by $15 \mathrm{Tg}$ per year.

(3) Improving animal management strategies may decrease $\mathrm{N}_{r}$ release by $\sim 15 \mathrm{Tg}$ per year.

(4) Improving conventional sewage treatment (especially in developing countries) may decrease the $\mathrm{N}_{\mathrm{r}}$ release into surface waters by $\sim 5 \mathrm{Tg}$ per year, by converting it to $\mathrm{N}_{2}$.

These suggested measures have great potential, but require also considerable efforts worldwide to implement these in practice. The measures may not threaten food and fuel securities, should not harm rural livelihoods and should not create a disproportionate large burden for a sector, group and/or area. This list only addresses part of the challenge in relation to emissions of $\mathrm{N}_{\mathrm{r}}$ to the environment in Europe.

\subsubsection{Key actions for major European sectors}

The European Union (EU) has various Directives and Regulations addressing $\mathrm{N}$ emissions from combustion, agriculture and households, and $\mathrm{N}$ deposition in terrestrial biosphere, air and waters (Oenema et al., 2011; Chapter 4, this volume). In reflecting on these, and the need to further develop a package for integrated management of $\mathrm{N}$ across sectors and actors in Europe, we identify the following seven key actions. These actions not only include technical and managerial measures for specific sectors, but also key actions related to patterns of societal consumption.

\section{Agricultural sector}

Agriculture is by far the largest user of nitrogen, needed for the production of food, feed and fibre (Jensen et al., 2011, Chapter 3 this volume), and also the largest emitter of $\mathrm{NH}_{3}$ and $\mathrm{N}_{2} \mathrm{O}$ to air and of $\mathrm{NO}_{3}$ to groundwater and surface waters in $\mathrm{EU}$ 
(de Vries et al., 2011; Leip et al., 2011, Chapters 15 and 16 this volume). It is also the sector that faces many different measures aimed at decreasing the losses of these $\mathrm{N}$ species (Oenema et al., 2011; Jarvis et al., 2011, Chapters 4 and 10 this volume). Given these arguments and the criteria above, it will be no surprise that agriculture is a central target for developing more integrated nitrogen management strategies in Europe. The following three key actions are suggested as the priority for European efforts to reduce $\mathrm{N}$ losses from agriculture.

- Action 1: Improving nitrogen use efficiency in crop production. Increasing crop yields through improving the genetic potential of crop varieties and improving soil, crop and $\mathrm{N}$ management, at similar $\mathrm{N}_{\mathrm{r}}$ inputs, increases nitrogen use efficiency. Lowering $\mathrm{N}_{\mathrm{r}}$ input through improved management and decreasing $\mathrm{N}$ losses, while maintaining crop yields has a similar effect. Strategies aimed at increasing nitrogen use efficiency decrease $\mathrm{N}_{\mathrm{r}}$ losses per unit of produce, with minimal risk of pollution swapping (Tilman et al., 2002). Currently, there are no specific requirements, incentives or targets in EU agriculture to increase $\mathrm{N}$ use efficiency, though some policies contribute (Oenema et al., 2009). Where possible, such interventions should be combined with improving use efficiencies of phosphorus, water, pesticides, etc., in crop production.

- Action 2: Improving nitrogen use efficiency in animal production. Increasing animal productivity through improving the genetic potential of the animals, decreasing maintenance costs, and improving feed quality increases feed conversion efficiency and nitrogen use efficiency. Again, strategies aimed at increasing nitrogen use efficiency decrease $\mathrm{N}_{\mathrm{r}}$ losses per unit of produce (Steinfeld et al., 2010). Similarly, there are currently no specific requirements or targets to improve animal nitrogen use efficiency in Europe. Where possible, such interventions should be combined with improving use efficiencies of phosphorus, micronutrients, antibiotics, etc., in animal production.

- Action 3: Increasing the fertilizer $\mathbf{N}$ equivalence value of animal manure. Farm animals excrete via dung and urine $60 \%-90 \%$ of the $\mathrm{N}_{\mathrm{r}}$ (and other nutrients) in the animal feed. A large proportion of this $\mathrm{N}_{\mathrm{r}}$ (up to $90 \%$ ) can be used again for nourishing crops, but the reality is that on most farms only a relatively small fraction is re-utilized again. Increasing the fertilizer equivalence values requires conserving the $\mathrm{N}$ in the manure during storage and land application (especially requiring techniques to reduce $\mathrm{NH}_{3}$ emissions where a large fraction of the $\mathrm{N}_{\mathrm{r}}$ is lost), while optimizing the rate and time of application to crop demand. Currently, there are no specific targets for the fertilizer $\mathrm{N}$ equivalence values in EU agriculture, apart from some Member States that have formulated target values in Nitrate Action Plans within the framework of the EU Nitrates Directive. Also, there are few requirements to use manure application techniques with low $\mathrm{N}_{\mathrm{r}}$ emissions, although the Nitrates Directive and CLRTAP Gothenburg Protocol do recognize the need to use manure $\mathrm{N}_{\mathrm{r}}$ efficiently. Further, phosphorus and other nutrients, including micro-nutrients like copper and zinc in manures, should be used efficiently too.

\section{Energy, industry and transport sectors}

The energy, industry and transport sectors are by far the largest users of fossil energy and the largest emitters of $\mathrm{NO}_{\mathrm{x}}$ to the atmosphere. Significant reductions in $\mathrm{NO}_{\mathrm{x}}$ have been achieved during the last two decades (Erisman et al., 2011; Moldanová et al., 2011, Chapters 2 and 18 this volume), but the health impacts of $\mathrm{NO}_{\mathrm{x}}$ emissions in $\mathrm{EU}$ are still large (Brink et al., 2011, Chapter 22 this volume), and there is scope for further mitigation.

- Action 4: Low-emission combustion and energyefficient systems. There are many methods available to reduce $\mathrm{NO}_{\mathrm{x}}$ emissions from both stationary combustion sources and vehicles (Erisman et al., 2011, Chapter 2 this volume). At the same time, there are possibilities for increasing energy-efficiency and for alternative energy sources with less emissions. Although some of the emission abatement methods can increase emissions of $\mathrm{NH}_{3}$ and $\mathrm{N}_{2} \mathrm{O}$, technological advances are reducing these tradeoffs. Overall, these advances represent an important technical success of existing policies that should be continued in the future. In addition, $\mathrm{NO}_{\mathrm{x}}$ emissions from shipping (currently $\sim 20 \%$ of total emissions in EU) need to be addressed (Hertel et al., 2011, Simpson et al., 2011, Chapters 9 and 14 this volume). At the same time, there is a great need to increase the energy-use efficiency and to develop alternative energy sources. It is suggested to strengthen and to further integrate abatement strategies for $\mathrm{NO}_{\mathrm{x}}$ emissoins with strategies that increase energy use efficiency and develop clean energy sources. Steps are already being made under the ongoing revisions of the CLRTAP Gothenburg Protocol, the EU National Emissions Ceilings (NEC) Directive and the EU Integrated Pollution Prevention and Control (IPPC) Directive (Oenema et al., 2011).

\section{Sewage treatment sector}

Sewage from households and industry is a major source of pollution of surface waters from $\mathrm{N}_{\mathrm{r}}$ and phosphorus, in part because current sewage treatment is far from optimal. As noted above, Galloway et al. (2008) highlighted the global potential for increased waste water treatment, encouraging the conversion of anthropogenically produced $\mathrm{N}_{\mathrm{r}}$ back to $\mathrm{N}_{2}$. Such treatment systems are already in widespread use across Europe, being based on removing $\mathrm{N}_{\mathrm{r}}$ from the sewage through sequential nitrification and denitrification with di-nitrogen $\left(\mathrm{N}_{2}\right)$ as main end product. However, this approach has the risk of significant $\mathrm{N}_{2} \mathrm{O}$ release, and also represents a waste of the energy used to produce $\mathrm{N}_{\mathrm{r}}$. Novel techniques are in development based in part on old practices.

- Action 5: Recycling nitrogen (and phosphorus) from waste water systems. There is potential for new sewage systems that recycle the nitrogen contained in the wastes, for use in crop production. These systems have to be further developed and tested (Sviriejeva-Hopkins et al., 2011, Chapter 12 this volume; see also Supplementary materials). Such approaches have the potential co-benefit of recycling phosphorus and can generate bio-energy at the same time 
(Magid et al., 2006). Over the next decades, where new sewage systems are planned (such as for new towns and cities) or major reconstructions of existing sewage systems become necessary, it should become a target to recycle sewage $\mathrm{N}_{\mathrm{r}}$ rather than denitrify it back to $\mathrm{N}_{2}$.

\section{Societal consumption patterns}

Society at large is ultimately responsible for the anthropogenic $\mathrm{N}_{\mathrm{r}}$ emissions and can have a considerable influence on these emissions. Alteration of societal consumption patterns is also a most integral management measure as it harbours synergistic environmental effects (See Supplementary materials). Two key options emerge.

- Action 6: Energy and transport saving. Against the success of technical measures to reduce $\mathrm{NO}_{\mathrm{x}}$ emissions per unit consumption, both vehicle miles and energy use have increased substantially over past decades. Dissuasion of polluting cars and far-distance holidays, and stimulation of energy-saving houses and consumption patterns can greatly contribute to decreasing $\mathrm{NO}_{\mathrm{x}}$ emissions. The approach is fully aligned with efforts to reduce per capita energy use and $\mathrm{CO}_{2}$ emissions. Over the last decades, emissions per $\mathrm{km}$ have decreased (due to existing policy measures and advancements in technology), but the number of drivers and the number of $\mathrm{km}$ per driver have increased.

- Action 7: Lowering animal protein consumption. Meat, milk and eggs contain high quality protein (amino acids), vitamins and micronutrients for humans. However, the current human consumption of protein from meat, milk, and eggs is far above the recommended per capita consumption in many parts of Europe. Lowering the per capita consumption to the recommended level will decrease the $\mathrm{N}_{\mathrm{r}}$ release associated with the production of meat, milk, and eggs and will have positive human health effects where the current consumption is over the optimum (see also Winiwarter et al., 2011; Reay et al., 2011, Chapters 24 and 26 this volume). Moreover, the $\mathrm{N}$ cost of producing protein in milk, egg and poultry is much less than that in pork and especially beef, indicating that a shift from beef to pork to poultry and milk would also decrease $\mathrm{N}_{\mathrm{r}}$ use (Steinfeld et al., 2010; see also Jarvis et al., 2011, Chapter 10 this volume).

This list of seven key actions together provides a package that addresses the major sources of $\mathrm{N}_{\mathrm{r}}$ to the environment. These are naturally not the only measures that should be considered. For example, better spatial and temporal planning approaches to landscape management, watershed management and airshed management (Cellier et al., 2011; Billen et al., 2011; Simpson et al., 2011, Chapters 11, 13 and 14 this volume) are needed and can contribute significantly. Such further actions will need to take account of patterns in each of the key societal threats of excess $\mathrm{N}_{\mathrm{r}}$ : water quality, air quality, greenhouse gas balance, ecosystems and biodiversity, and soil quality (Grizzetti et al., 2011; Moldanová et al., 2011; Butterbach-Bahl et al., 2011; Dise et al., 2011; Velthof et al., 2011, Chapters 17-21 this volume). They will also need to consider the relative societal costs of these threats and the future outlook (Brink et al., 2011, Winiwarter et al., 2011; Chapters 22 and 23 this volume). However, by focusing on the source of emissions, the seven key actions listed here provide the basic foundation for integrated $\mathrm{N}_{\mathrm{r}}$ management.

\subsection{Concluding remarks}

Integrated $\mathrm{N}$ management approaches have existed largely unconsciously since human beings have started to cultivate land and found out that the land does not provide food for free. Nevertheless, the specific request for developing integrated $\mathrm{N}$ management approaches emerged only two decades ago, following the increased awareness of the large emissions, its huge impacts, and the complexity and partial effectiveness of emission abatement measures. Indeed, the promise of integrated $\mathrm{N}$ management approaches lies in the increased effectiveness and efficiency of emissions abatement measures. An integrated approach to $\mathrm{N}$ also holds the promise of decreasing the risks on pollution swapping, but puts higher demands on interdisciplinary cooperation and consensus building both in the domains of science and policy. However, there is as yet little quantitative empirical evidence for these promises.

Discussions about integrated approaches have often been confusing, in part because of a lack of clear concepts and definitions. This chapter provides a framework for developing and analyzing integrated approaches. It distinguishes five dimensions for developing integrated $\mathrm{N}$ management approaches. It builds on existing concepts and approaches. There is a need for improving and testing the framework further so as to achieve a better understanding of the effects of 'integration' on the effectiveness and efficiency of $\mathrm{N}$ management, and possibly a more insightful framework.

Integrated approaches often have two opposite images. The one refers to a compact and fully integrated and smart approach, like a chip in electronics. The other refers to a complex approach, with many add-ons, that evokes the image of unclearness. Both images are indeed possible. The difference lies in the coalescence and organization, which makes the first effective as a functional whole and the latter potentially less effective. Clearly, integrated management approaches are demanding in terms of knowledge, organization, logistics, chain management and optimization.

Given these issues, it is essential that approaches to integrated $\mathrm{N}_{\mathrm{r}}$ policies take a stepwise approach, focusing on clearly identified priorities and an achievable level of integration at each stage. In this respect, the seven key actions identified here provide an important focus for the next stage of the societal and policy dialogue. Together they make the links between the five societal threats of excess $\mathrm{N}_{\mathrm{r}}$ in the environment, and can be used to guide future mitigation and adaptation strategies.

\section{Acknowledgements}

This chapter was prepared with the support of the NinE Programme of the European Science Foundation, the NitroEurope IP (funded by the European Commission) and the COST Action 729. The UK Department for Environment, Food 
and Rural Affairs (Defra) and the Netherlands Ministry for Agriculture, Nature and Food Quality (LNV) are also thanked for their support of the UNECE Task Force on Reactive Nitrogen to which this work contributes.

\section{Supplementary materials}

Supplementary materials (as referenced in the chapter) are available online through both Cambridge University Press: www.cambridge.org/ena and the Nitrogen in Europe website: www.nine-esf.org/ena.

\section{References}

Billen, G., Silvestre, M., Grizzetti, B. et al. (2011). Nitrogen flows from European watersheds to coastal marine waters. In: The European Nitrogen Assessment, ed. M. A. Sutton, C. M. Howard, J. W. Erisman et al., Cambridge University Press.

Brink, C., van Grinsven, H., Jacobsen, B. H. et al. (2011). Costs and benefits of nitrogen in the environment. In: The European Nitrogen Assessment, ed. M. A. Sutton, C. M. Howard, J. W. Erisman et al., Cambridge University Press.

Bull, K., Hoft, R. and Sutton, M. A. (2011). Co-ordinating European nitrogen policies between directives and international conventions. In: The European Nitrogen Assessment, ed. M. A. Sutton, C. M. Howard, J. W. Erisman et al., Cambridge University Press.

Butterbach-Bahl, K., Nemitz, E., Zaehle, S. et al. (2011). Nitrogen as a threat to the European greenhouse balance. In: The European Nitrogen Assessment, ed. M. A. Sutton, C. M. Howard, J. W. Erisman et al., Cambridge University Press.

Cellier, P., Durand, P., Hutchings, N. et al. (2011). Nitrogen flows and fate in rural landscapes. In: The European Nitrogen Assessment, ed. M. A. Sutton, C. M. Howard, J. W. Erisman et al., Cambridge University Press.

de Vries, W., Leip, A. Reinds, G. J. et al. (2011). Geographic variation in terrestrial nitrogen budgets across Europe. In: The European Nitrogen Assessment, ed. M. A. Sutton, C. M. Howard, J. W. Erisman et al., Cambridge University Press.

Dise, N. B., Ashmore, M., Belyazid, S. et al. (2011). Nitrogen as a threat to European terrestrial biodiversity. In: The European Nitrogen Assessment, ed. M. A. Sutton, C. M. Howard, J. W. Erisman et al., Cambridge University Press.

EC (2010). Water Framework Directive (WFD; 2000/60/EC). http://ec.europa.eu/environment/water/water-framework/ index_en.html

EEA (1995). Europe's Environment: the Dobris Assessment. European Environment Agency, Copenhagen

Erisman, J. W., van Grinsven, H., Grizzetti, B. et al. (2011). The European nitrogen problem in a global perspective. In: The European Nitrogen Assessment, ed. M. A. Sutton, C. M. Howard, J. W. Erisman et al., Cambridge University Press.

Galloway, J. N. and Cowling, E. B. (2002). Reactive nitrogen and the world: 200 years of change. Ambio, 31, 64-71.

Galloway, J. N., Aber, J. D. Erisman, J. W. et al. (2003). The nitrogen cascade. BioScience, 53, 341-356.

Galloway, J. N., Townsend, A. R. Erisman, J. W. et al. (2008). Transformation of the nitrogen cycle: recent trends, questions and potential solutions. Science, 320, 889-892.

Grizzetti, B., Bouraoui, F., Billen, G. et al. (2011). Nitrogen as a threat to European water quality. In: The European Nitrogen Assessment, ed. M. A. Sutton, C. M. Howard, J. W. Erisman et al., Cambridge University Press.
Hall, C. A. S., Lindenberger, D., Kummell, R., Kroeger T. and W. Eichorn, (2001). The need to reintegrate the natural sciences with economics. BioScience, 51, 663-673.

Hertel, O., Reis, S., Ambelas Skjøth, C. et al. (2011) Nitrogen turnover processes in the atmosphere. In: The European Nitrogen Assessment, ed. M. A. Sutton, C. M. Howard, J. W. Erisman et al., Cambridge University Press.

Jarvis, S., Hutchings, N., Brentrup, F., Olesen, J. and van der Hoek, K. (2011). Nitrogen flows in farming systems across Europe. In: The European Nitrogen Assessment, ed. M. A. Sutton, C. M. Howard, J. W. Erisman et al., Cambridge University Press.

Jensen, L. S., Schjoerring, J. K., van der Hoek, K. et al. (2011) Benefits of nitrogen for food fibre and industrial production. In: The European Nitrogen Assessment, ed. M. A. Sutton, C. M. Howard, J. W. Erisman et al., Cambridge University Press.

Kahn, P. H. (2001). The Human Relationship with Nature: Development and Culture, MIT Press, Cambridge, MA.

Leip, A., Achermann, B., Billen, G. et al. (2011). Integrating nitrogen fluxes at the European scale. In: The European Nitrogen Assessment, ed. M. A. Sutton, C. M. Howard, J. W. Erisman et al., Cambridge University Press.

Magid, J., Eilersen, A. M., Wrisberg, S. and Henze, M., (2006). Possibilities and barriers for recirculation of nutrients and organic matter from urban to rural areas: a technical theoretical framework applied to the medium-sized town Hillerod, Denmark. Ecological Engineering, 28, 44-54.

Moldanová, J., Grennfelt, P., Jonsson, Å. et al. (2011). Nitrogen as a threat to European air quality. In: The European Nitrogen Assessment, ed. M. A. Sutton, C. M. Howard, J. W. Erisman et al., Cambridge University Press.

Odum, E. P. (1996). Ecology: A Bridge between Science and Society, Sinauer Associates, Sunderland, MA.

OECD (1991). Environmental Indicators: A preliminary Set, OECD, Paris.

OECD (2007). Instrument Mixes for Environmental Policy, OECD, Paris.

Oenema, O., Kros, H. and de Vries, W. (2003). Approaches and uncertainties in nutrient budgets: implications for nutrient management and environmental policies. European Journal of Agronomy, 20, 3-16.

Oenema, O., Witzke, H. P., Klimont, Z. Lesschen, J. P. and Velthof, G. L. (2009). Integrated assessment of promising measures to decrease nitrogen losses from agriculture in EU-27. Agriculture, Ecosystems and Environment, 133, 280-288.

Oenema, O., Bleeker, A., Braathen, N. A. et al. (2011). Nitrogen in current European policies. In: The European Nitrogen Assessment, ed. M. A. Sutton, C. M. Howard, J. W. Erisman et al., Cambridge University Press.

Reay, D. S., Howard, C. M., Bleeker, A. et al. (2011). Societal choice and communicating the European nitrogen challenge. In: The European Nitrogen Assessment, ed. M. A. Sutton, C. M. Howard, J. W. Erisman et al., Cambridge University Press.

Rotmans, J. (2003). Transition Management: Key to a Sustainable Society (in Dutch), Koninklijke Van Gorcum, Assen, The Netherlands.

Simpson, D., Aas, W., Bartnicki, J. et al. (2011). Atmospheric transport and deposition of nitrogen in Europe. In: The European Nitrogen Assessment, ed. M. A. Sutton, C. M. Howard, J. W. Erisman et al., Cambridge University Press.

Smil, V. (2001). Enriching the Earth, MIT Press, Cambridge, MA.

Steinfeld, H., Mooney, H., Schneider, F. and Neville, L. E. (eds.) (2010). In: Livestock in a Changing Landscape: Drivers, Consequences and Responses, Island Press, Washington, DC. 
Sutton, M. A., Howard, C. M., Erisman, J. W. et al. (2011). The need to integrate nitrogen science and policies. In: The European Nitrogen Assessment, ed. M. A. Sutton, C. M. Howard, J. W. Erisman et al., Cambridge University Press.

Svirejeva-Hopkins, A., Reis, S., Magid, J. et al. (2011). Nitrogen flows and fate in urban landscapes. In: The European Nitrogen Assessment, ed. M. A. Sutton, C. M. Howard, J. W. Erisman et al., Cambridge University Press.

Tilman, D., Cassman, K. G., Matson, P. A., Naylor, R. and Polasky, S. (2002). Agricultural sustainability and intensive production practices. Nature, 418, 671-677.

TFIAM/CIAM (2007). Reviews of the Gothenburg Protocol, MNP, Bilthoven, and IIASA, Laxenburg, Austria, The Netherlands.

UNECE (1999). Protocol to the 1979 Convention on Long-Range Transboundary Air Pollution to Abate Acidification, Eutrophication and Ground-Level Ozone. http://www.unece.org/env/lrtap/ multi_h1.htm

Tuinstra, W., Hordijk, L. and Kroeze, C. (2006). Moving boundaries in transboundary air pollution: co-production of science and policy under the Convention of Long-Range Transboundary Air Pollution. Global Environmental Change, 16, 349-363.

Velthof, G., Barot, S., Bloem, J. et al. (2011). Nitrogen as a threat to European soil quality. In: The European Nitrogen Assessment, ed. M. A. Sutton, C. M. Howard, J. W. Erisman et al., Cambridge University Press.

Winiwarter, W., Hettelingh, J. P., Bouwman, L. et al. (2011). Future scenarios of nitrogen in Europe. In: The European Nitrogen Assessment, ed. M. A. Sutton, C. M. Howard, J. W. Erisman et al., Cambridge University Press. 